\title{
Mobile Innovative Transformational Ecosystem of Management of Humane Technological Society
}

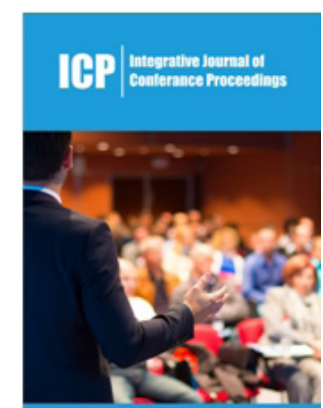

*Corresponding author: Evgeniy Bryndin, International American Academy of Education, Russia

Submission: 侮 May 16, 2019

Published: 海 May 23, 2019

Volume 1 - Issue 2

How to cite this article: Evgeniy $B$. Mobile Innovative Transformational Ecosystem of Management of Humane Technological Society. Int J Conf Proc.1(3). ICP.000512.2019.

Copyright@ Evgeniy Bryndin, This article is distributed under the terms of the Creative Commons Attribution 4.0 International License, which permits unrestricted use and redistribution provided that the original author and source are credited.

\author{
Evgeniy Bryndin* \\ International American Academy of Education, Russia
}

\begin{abstract}
Accumulation of modern knowledge, training and development of skills of basic researches of the phenomena, processes, objects and laws of the real world and also applied multi-boundaries-a trancedisciplinary researches in the priority directions of scientific technical progress and strategically important industries has to be the main task of an ecosystem of higher educational institutions. Education must be continuous and competitive. The ecosystem of education must continue to train necessary competitive experts. For this purpose, participation of wide groups of interested parties in development and expansion of transformational instruments of training is necessary. Communication of educational and scientific activity, their joint actions is real means of increase in efficiency of transformation of innovative competitive education. Joint actions of science and creative innovative higher education accelerate training of highly skilled personnel. Reproduction of highly skilled personnel has a high priority. Large corporations must make enough investments into scientific research in the field of high technologies, training of experts of the corresponding quantity and quality to create the system of publicprivate partnership in the sphere of the higher education. Creation of big educational complexes which are based on a joint action of the university and the industrial sector-one of the most important directions for development of the hi-tech industry. Joint actions of science and education - an indispensable condition of development of hi-tech humane society.
\end{abstract}

Keywords: Creativity; Transformational education; Innovations; Researches; Synergy

\section{Introduction}

Innovative processes of society cover economy, the social sphere, policy, education, science, the equipment, production, business and other spheres. In hi-tech society the major role in its development is played by the new ideas and innovations. At an innovative stage of development information and knowledge becomes objects of creative thinking what product the new ideas having big social and economic effect. At the same time after transition to a new stage all achievements of the previous stages remain and develop at higher level. Creativity in the developed society becomes a continuous rule and the main source of competitive advantage. Practically any area of production wins if there is a creative potential. Task of educational institutions to prepare humane hi-tech professionals. Today modern education accepts the strategy of formation of hi-tech humane society.

\section{Formation of humane hi-tech society}

Creation of humane hi-tech society (Society 5.0) is carried out by the countries with the hi-tech industry and high culture, such as Japan, China and many others. First, it is necessary to create society in which comfortably to everyone. Any person can and wants to take active part in society life. Important aspect of society 5.0 is creation of equal opportunities for all and providing the environment for realization of potential of each person. In Society 5.0 by means of technologies it is necessary to remove physical, administrative and social barriers to self-realization of the person and development of technologies and to lead to steady social and economic growth. The purpose of Society 5.0 at the level of authorities to set the direction of technological development and to motivate the large companies on creation of socially oriented technologies by means of which private corporations and businessmen make the contribution to improvement of life of people. The mankind crossed line of technological 
development when the Planet became vulnerable. Will help to rescue mankind from an ecological disaster, ecological thinking and behavior of people, and their ecological responsibility, the moral relation to the nature; harmonization of vital system by waste-free industrial cycles of the combined productions; eco-world formation. The problem of global ecological stabilization can be solved by implementation of social and economic interdisciplinary programs, such as, first, the ecological program "Clean Air, Clear Water, Pure Food, Net Energy, Pure Cities and Villages, Pure Nature", secondly, the program of development ecological and health the preserving with the filled economy resources, thirdly, the "Development Health of the Preserving Medicine and Health System" program, fourthly, the program of the ecological focused interdisciplinary education, fifthly, the program of peaceful, humane environmental policy, sixthly, the program of civil education of harmonious life for a sustainable development, seventhly, the program of formation of fair democracy as way of life of society. Social and economic programs for stabilization of ecology need to be realized under the competent direction and control of the institutionalized infrastructure of scientific and educational society and based on ecological thinking and behavior of all segments of the population. World community will have to undertake decisive measures to stabilize the environmental ecological processes in order to keep modern and future generations supplied with a harmony between the meeting of their reasonable needs, social and economic problems decision, with the life on the Earth being preserved. Society 5.0 is the strategy of changes based on penetration of digital technologies into all spheres of human existence. The companies must integrate into social infrastructure new decisions for improvement of quality of life of citizens. Technological progress must be directed to the benefit of society. If there is no it, both economic, and social degradation will be a consequence. Technologies as IoT, IoE and others, must create new spheres of application of human talents, knowledge and abilities, so and new opportunities for employment. The companies should not dismiss the person just like that. They must find an opportunity to provide to the person a new position. If its level does not correspond-they must invest in the program of retraining. Development of a human resource must become one of priorities. Anyway, people must study new. Approaches to education that it became more dynamic, with flexible skills must be reconsidered, to answer the current inquiries. Business must cooperate actively with the universities to participate in education of new generation of the engineers ready to work with clever systems. Success of formation of society 5.0 directly depends on system synergy of development, how in common and harmoniously business community, authorities, the universities and social institutes will work on the solution of social and economic tasks.

\section{Economy of digital technologies}

Achievements in robotics, artificial intelligence and technologies of automation allowed the companies to use in various sectors of economy them for higher performance, a quality product and for management of operations in the system of deliveries, autonomous vehicles, trade in the financial markets. The large and small companies use a chat-bots to maintain their relations with clients. Social robots enter actively our life. It led to huge transformations of ways which people live and work. Technical achievements in the industry 4.0 throw down a challenge to human work in the sphere of production [1-8]. The automated production undermines the economic principle of the theory of cost which was attributed by such thinkers as Karl Marx, Adam Smith and David Ricardo. With fast achievements in robotics and artificial intelligence, human work becomes necessary less. Widespread introduction of the automated economy will lead to a new economic and social landscape in which there will be winners and losers. Technological ability to replace human work it is easy, and the cheapest way new technologies will lead to new political economy. It will be the new world in which the most part of work in terms of production of goods and services is created by robots. Whether robots will be used generally as additions to human work or replacement of human work. There is a problem of stability of such economic systems as cars do not consume goods and services, unlike people. Producers can make high-quality goods at low price for unit, but there is a question who will be able to buy goods and services. Other political and economic trend which will influence new economy is a by-product of global economy. As economic systems are interconnected more than ever before now and, there are considerable advantages to those who win the market early. There are many reasons of it, including digitizing, improvements of communications (and transportation) and the increased importance of networks and standards. Networks allow dissemination of information and services more than ever before, allowing establishment of monopolies. Creation of the markets outside the prevailing channels and networks become harder and harder.

\section{Influence of digital technologies on labor market}

The first and main influence of technologies will be elimination of jobs through automation. Though there will be a lot of lost jobs, new jobs will also be created, and other jobs will change. Automation of many processes can happen on productions in which labor costs are well-known high. The need for people will carry out productions which cars cannot make, or which people can execute still better, then cars. Exclusive distinctions will increase as takes place almost in all developed countries in the last decades as work will consist of the skilled workers based on knowledge and smaller quantity few skilled workers. Those which are less qualified will constantly face a competition to robots and artificial intelligence which will undermine prestigiousness of human work. There will be some specializations which remain difficult to replace with robots or artificial intelligence, and these provisions will continue to function though there will be pressure towards decrease in such jobs. Profit for those which work at such works will decrease. They should not feel safe also as there is a technical progress which can reduce their work. With reduction of number of the people working and paying taxes on their income the economy of uniform prosperity providing living income to the population $[9,10]$ must be created. The uniform economy of uniform prosperity can be created by means of mobile management of productions where jobs 
are served according to a certain schedule by several competent experts. Such economy and its laws assume workers - the people paying taxes from their salary and assume that such human work is necessary to support economic systems. Laws also assume that people are busy not with full employment in which people have stable income and advantages, meaning that many laws, regulating mobile work, assume mobile industrial model of work. The new economy, to a large extent, will depend on short-term contracts.

\section{Competitive stay in labor market}

The near future will demand the qualified human resources. At the World Economic Forum of 2018 ten necessary professional skills in 2020 were marked out: ability, the difficult solution of tasks, critical thinking, creativity, human resource management, coordinating and synergy with others, emotional intelligence and mental balance, judgment and decision-making, service orientation, negotiations, informative flexibility. These key skills determined by the World Economic Forum assume that competitive advantage which people have with robots and artificial intelligence is not based on their physical state, but on intellectual opportunities and competent skills to carry out the innovative volume of a workplace. Development of such skills is gained through education/training, the accumulated experience and natural mental ability. Education will have to develop those talents which are useful in economy. New approach to education, which is based on development of human skills is necessary to consider needs of people for human resources which will have to gain new skills to be relevant in the flexible and changing economy [11]. As many employees will change jobs and industries, they will need the corresponding education which will allow them to have the corresponding skills in new positions which they will take in various companies and areas. The companies will also have to take a part of responsibility for training and retraining of employees, and such responsibility should not be exclusive responsibility of the universities isolated from the innovative hitech industry in many respects. In intellectual creative innovative hi-tech economy people, educational systems and the industry will change.

\section{Robot with technological thinking and behavior on service of society}

Robots become independent subjects of social environment [1217]. Social cognitive smart robots are used as guide, seller, lecturer, vacuum cleaner, nurse, volunteer, security guard, administrator of hotel. Japanese robot-administrator of hotel Henn-na Hotel (Figure 1). Smart guide (Figure 2). Smart taxi (Figure 3). Robot-Android volunteer ASIMO (Figure 4). Mobile robot security guard Atlas (Figure 5).

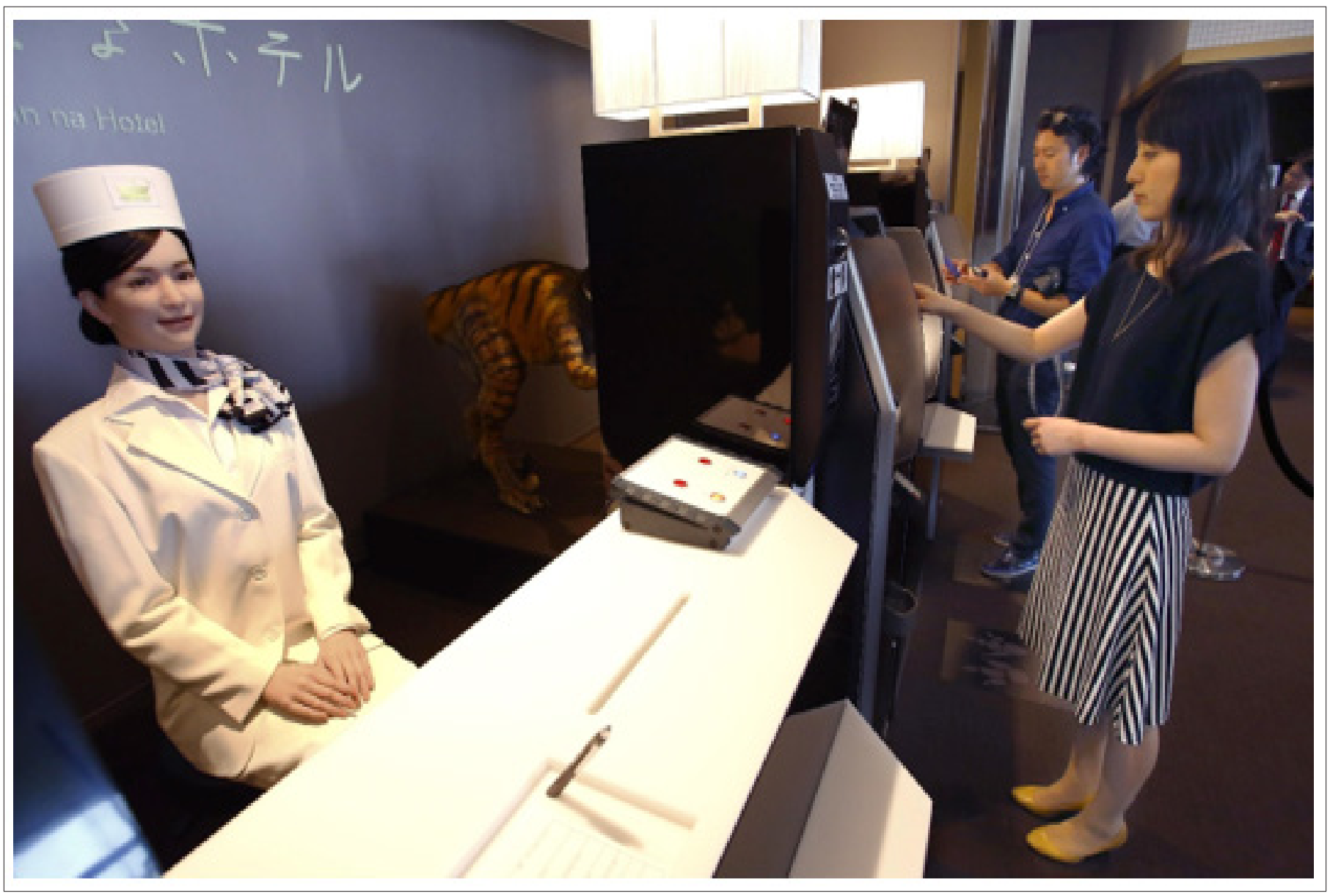

Figure 1: Japanese robot-administrator of hotel Henn-na Hotel. 


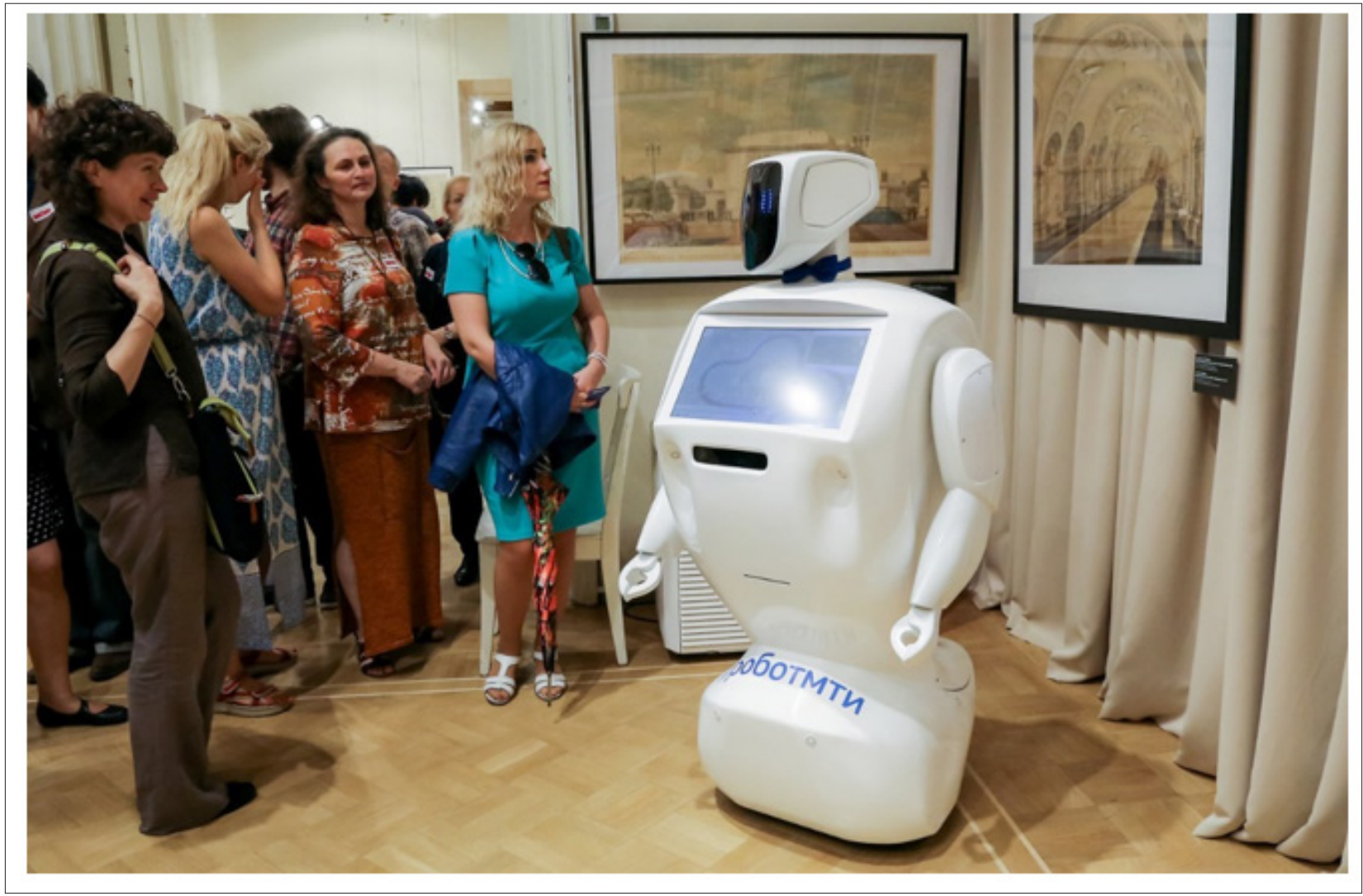

Figure 2: Russian robot guide.

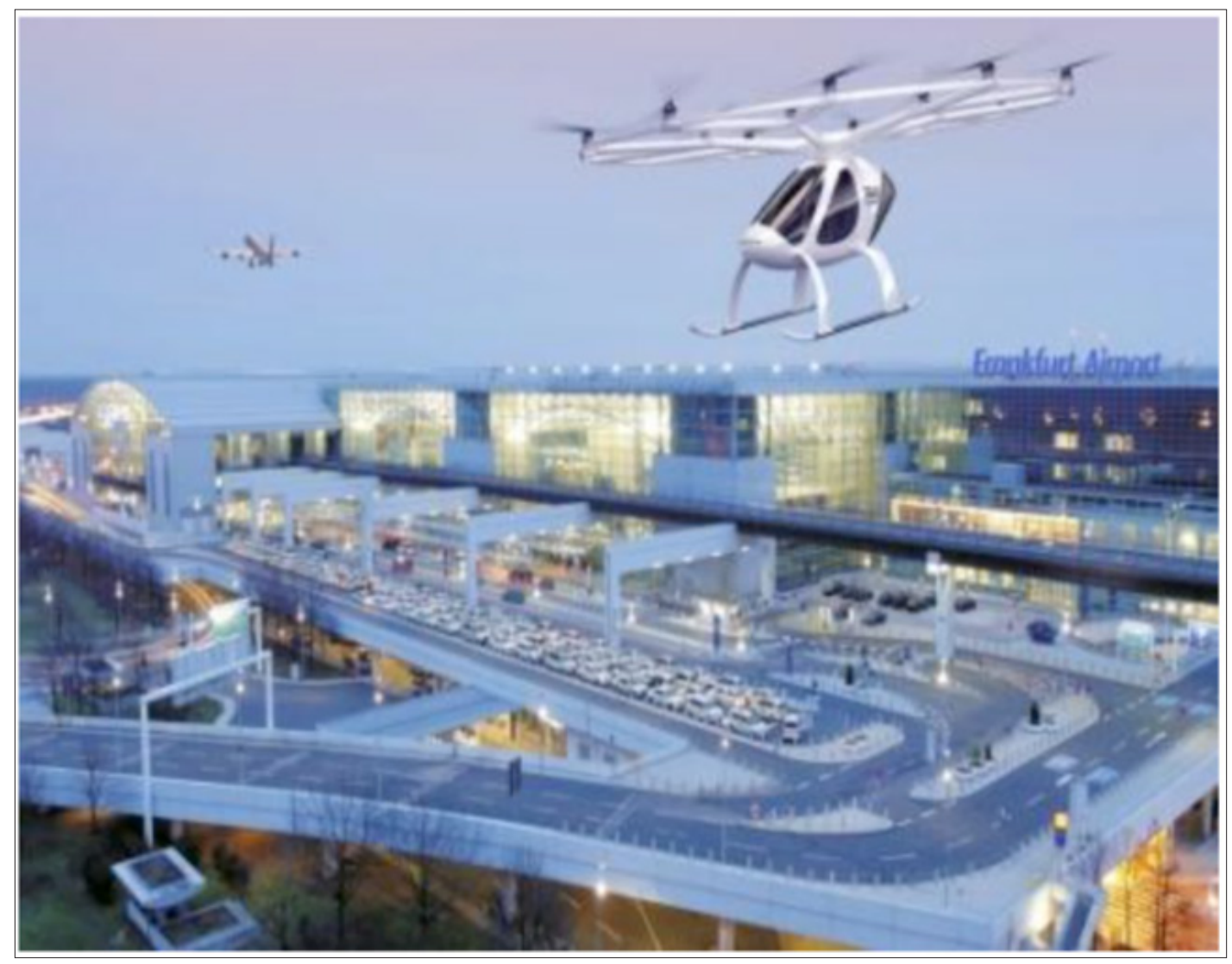

Figure 3: European taxi. 


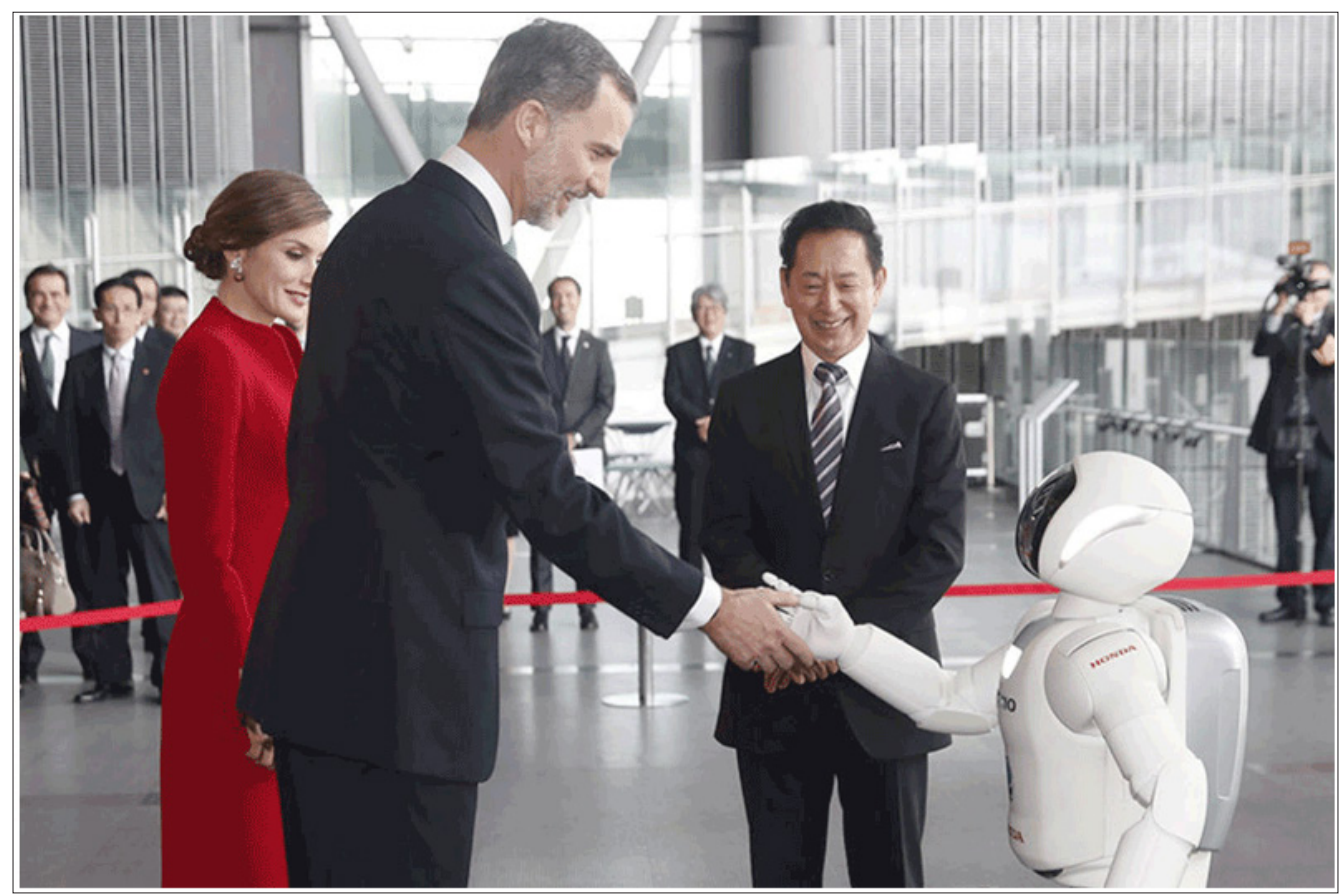

Figure 4: Japanese robot-android volunteer ASIMO.

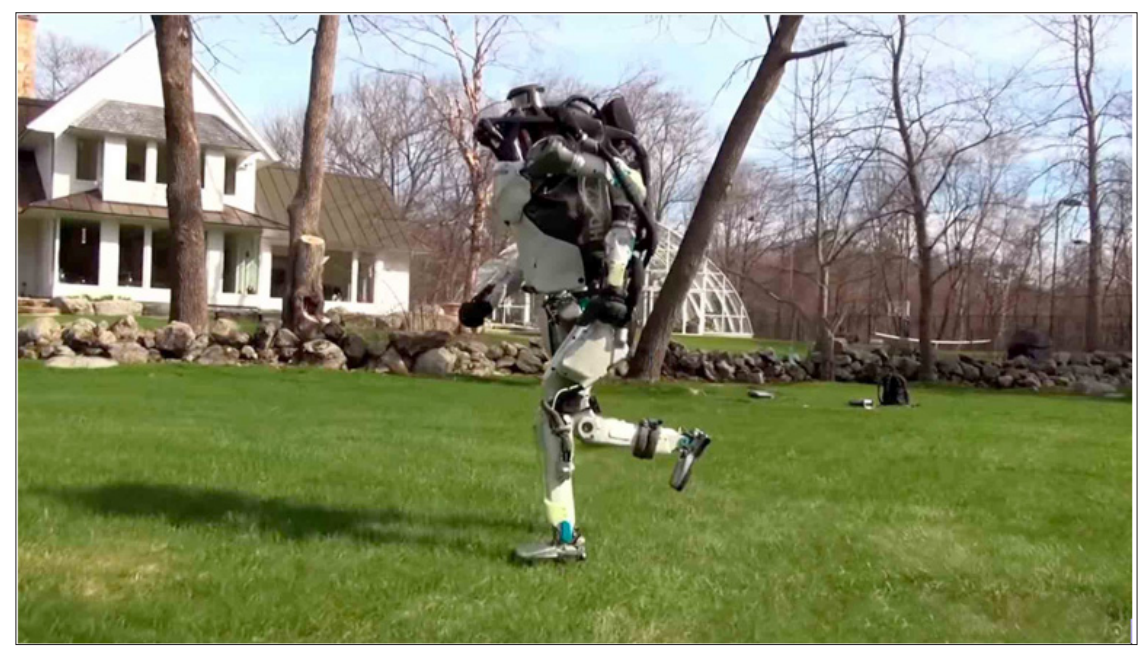

Figure 5: American mobile robot security guard atlas.

\section{Conclusion}

People will move away more and more from production of goods and services. Human work becomes not the main component in production. For people who lack skills to compete in innovative hi-tech economy, will compete with each other. The main concern about the assumptions of ability of the person to be able relevant in innovative hi-tech economy. While the World Economic Forum (2018) defined the skills necessary in a workplace, there is a question concerning whether all people have an ability and an opportunity to develop skills which are necessary for the industry. Many will be excluded from innovative hi-tech economy, just because of their inability and lack of opportunities to develop necessary skills. The government and education will have to change to be relevant and to be agreed with requirements of society which has more and more automated productive basis. Mobile management which will provide economic growth, first, must support the hi-tech enterprises, competitive in foreign market, with high added value (salary profit taxes). Secondly, to support the universities which train the highly qualified specialists who are knowing English, demanded in labor market, especially IT of experts of digital economy. Humane society is defined by its spiritual state. The spiritual condition of society is formed by spiritual life of citizens. Spiritual life is the most useful to the person and societies. The person neutralizes harmful thoughts and feelings, communication carries out ethical words, makes good deeds, fully discloses creative and innovative abilities. Society builds the smart cities and houses, keeps nature ecology, reaches uniform prosperity, establishes laws the eradicating defects and the spreading virtues. New knowledge of a creative innovative ecosystem of education improves practical skills of citizens on improvement of quality of life. Humane society becomes intellectual and nature technological. 


\section{References}

1. Evgeniy B (2018) Communicative associative logic of cognitive professional robot with imitative thinking. Journal Engineering Mathematics 2(2): 79-85.

2. Evgeniy B (2018) Directions of development of industry 4.0, digital technology and social economy. American Journal of Information Science and Technology 2(1): 9-17.

3. Evgeniy B (2017) Cognitive robots with imitative thinking for digital libraries, banks, universities and smart factories. International Journal of Management and Fuzzy Systems 3(5): 57-66.

4. Evgeniy B (2017) Program hierarchical realization of adaptation behavior of the cognitive mobile robot with imitative thinking. International Journal of Engineering Management 1(4): 74-79.

5. Evgeniy B (2018) Technological thinking, communication and behavior of androids. Communications 6(1): 13-19.

6. Evgeniy B (2019) Cognitive smart robots with technological thinking and behavior for industry and social sphere. Proceedings of articles the International scientific conference, Czech Republic.

7. Evgeniy B (2019) Digital technologies of the industry 4.0./Chapter 10, C 201-222. Nova Science Publisher, USA, p. 252.

8. Frey CB, Osborne MA (2017) The future of employment: how susceptible are jobs to computerisation? Technological Forecasting and Social Change 114(C): 254-280.

9. Evgeny B (2016) Economic aspect of global wellbeing. The European Proceedings of Social \& Behavioral Sciences 7: 14-21.
10. Bryndin EG (2018) Global social-economic stabilization. Scholar Journal of Applied Sciences and Research 1(3): 41-46.

11. Evgeniy B (2018) Creative innovative higher education of researchers with flexible skills and synergy of cooperation. Scientific Journal of Research and Review 1(2): 1-5.

12. Kiggins R (2018) The political economy of robots: prospects for prosperity and peace in the automated $21^{\text {st }}$ century. Cham: Palgrave Macmillan, USA.

13. Ivanov S, Webster C (2018) Adoption of robots, artificial intelligence and service automation by travel, tourism and hospitality companies-a costbenefit analysis. In: Marinov V, Vodenska M, Assenova M, Dogramadjieva E (Eds.), Traditions and Innovations in Contemporary Tourism (edn), Cambridge Scholars Publishing, USA, pp. 190-203.

14. Bhaumik A (2018) From AI to Robotics: Mobile, Social, and Sentient Robots. Boca Raton, CRC Press, Florida, USA.

15. Daugherty PR, Wilson HJ (2018) Human machine reimagining work in the age of AI. Harvard Business Review Press, Boston, Massachusetts, USA.

16. Carrozza MC (2019) The robot and us an anti-disciplinary perspective on the scientific and social impacts of robotics cham, Springer, USA, $p$. 20.

17. Ivanov S, Webster C (2017) The robot as a consumer: a research agenda. paper presented at the marketing: experience and perspectives conference, University of Economics-Varna, Bulgaria, pp. 71-79. 